\title{
POPULASI DAN KEANEKARAGAMAN HEWAN MAKROBENTHOS PADA PERAIRAN TERTUTUP DAN TERBUKA DI TELUK AWUR, JEPARA \\ MACRO BENTHIC ANIMAL POPULATION AND BIODIVERSITY IN CLOSED AND OPEN WATERS IN THE AWUR BAY, JEPARA
}

\author{
Ruswahyuni
}

Fakultas Perikanan dan Ilmu Kelautan, Universitas Diponegoro, Semarang J1. Prof. Sudharto, SH., Tembalang, Semarang 50147, Telp. 024 - 7460057

\begin{abstract}
Awur Bay waters is an area that has different water conditions, namely closed and open waters. Open water is an aquatic area facing the open sea without any barrier, island and the mainland either in front or in the form of open sea, so that open water is strongly influenced by waves and tides. Consequently in these waters, the waves interaction ,stream will cause turbulence. While the closed waters is impeded by inland waters or in the form of the bay therefore stream and wave power will reduce when it arrived at the beach. Macrobenthic animals are aquatic organisms that live in the bottom sediments, whether on top or in the bottom of sediments. Population is a group of individuals and the same species in a place and time, while indicating the presence of species diversity in ecosystems. The aims of the study is to analyze the difference effects of closed and open waters in the Awur bay Jepara, on the population and diversity of macrobenthic animals based on differences in the characteristics of the waters.
\end{abstract}

Key words : macro benthic animals, population, biodiversity

\section{Pendahuluan}

Daerah perairan terbuka serta tertutup di Teluk Awur menarik untuk diteliti karena dapat diketahui bagaimana hewan makrobenthos beradaptasi dengan lingkungannya. Perairan terbuka mempunyai kondisi lingkungan yang berbeda dengan perairan tertutup, terutama arus dan gelombang. Perbedaan arus dan gelombang inilah yang diduga akan menyebabkan adanya perbedaan terhadap populasi dan keanekaragaman hewan makrobenthosnya. Hal ini disebabkan karena arus dan gelombang dapat menyebabkan terjadinya pengadukan substrat yang akan berdampak terhadap terganggunya hewan makrobenthos yang hidup pada substrat yang teraduk tersebut.

Penelitian ini bertujuan untuk menganalisis perbedaan pengaruh perairan tertutup dan terbuka di Teluk Awur Jepara terhadap populasi dan keanekaragaman hewan makrobenthos yang didasarkan pada perbedaan karakteristik di perairan tersebut.

\section{Materi dan Metode Penelitian}

Hewan makrobenthos merupakan organisme air yang hidup dan tinggal di endapan dasar perairan, baik yang ada di atas maupun yang ada di bawah sedimen. Benthos hidup di perairan benthik (Odum, 1971). Hewan makrobenthos mendapatkan makanan dari dua bagian yaitu mikroalga benthik dan guguran dasar atau detritus yang suatu saat juga dapat tersuspensi oleh adanva pergerakan air (Barnes, 1980).

Hewan makrobenthos merupakan salah satu komponen penyusun ekosistem air laut Kelompok Polychaeta, Crustacea serta Mollusca lebih dominan dibandmg organisme lain. Perbedaan terletak pada komposisi organisme penyusunannya (Nybakken, 1992). Popuiasi adalah banyaknya organisme di suatu tempat atau daerah (Godman, 1989). Sedangkan popuiasi menurut Setiadi dan Tjondronegoro (1989), merupakan suatu kelompok individu dari spesies yang sama pada suatu tempat dan waktu. Popuiasi hewan makrobenthos erat kaitannya dengan faktor intrinsik dan ekstrinsik yang mempengaruhinya. Sebagaimana diungkapkan Krebs (1978), penyebaran dari lingkungan ditentukan oleh adanya sifat individu itu sendiri (intrinsik), yaitu sifat genetika dan kesenangan memilih habitat, serta adanya pengaruh dari luar (ekstrinsik) yaitu interaksi antara hewan makrobenthos dengan lingkungannya.

Keanekaragaman menunjukkan keberadaan spesies dalam ekosistem (Krebs, 1978). Suatu cara untuk menyatakan indeks keanekaragaman adalah dengan persentase komposisi spesies dalam contoh, dimana semakin tinggi nilai indeks keanekaragaman berarti semakin banyak spesies dalam contoh (Odum, 
1971). Semakin banyak spesies atau genera yang terdapat dalam sampel yang diambil semakin besar keanekaragamannya, meskipun harga ini sangat tergantung dari jumlah total masing-masing individu spesies atau genera tersebut (Nybakken, 1992).

Perairan terbuka adalah suatu daerah perairan yang menghadap ke arah laut lepas tanpa adanya penghalang baik itu pulau maupun daratan di depannya Sehingga perairan terbuka sangat dipengaruhi oleh ombak dan gelombang, sebagaimana diungkapkan oleh Mann (1982), perairan terbuka adalah perairan yang tidak terlindung serta dipengaruhi oleh ombak dan gelombang. Pergerakan ombak merupakan faktor yang penting di daerah ini. Pada dasar yang lunak, jalur ombak ini dapat menimbulkan gerakan bergelombang besar di dasar. Pada perairan ini, interaksi ombak dan arus menimbulkan turbulensi. Akibat turbulensi ini, perairan terbuka mengalami gangguan terhadap stabilitas substrat dimana partikel substrat dapat teraduk dan tersuspensi kembali, selain itu juga menyebabkan berkurangnya intensitas cahaya matahari yang masuk akibat air yang keruh sehingga mempengaruhi produktivitas pada perairan tersebut. Hal ini sangat mempengaruhi hewan infauna yang hidup di dalam substrat tersebut. Pergerakan ombak juga menentukan tipe partikel yang terkandung. Pergerakan ombak yang kuat memudahkan partikel halus sebagai suspensi (Nybakken, 1992).

Perairan tertutup adalah perairan yang terhalang oleh daratan atau pulau di depannya atau berupa teluk. Sehingga kekuatan arus dan gelombang akan bekurang ketika sampai di pantai. Perairan tertutup biasanya sebagian besar terbentuk dari susunan pasir, lumpur atau silt yang dihasilkan dari hasil sedimentasi atau pengendapan, biasanya terletak di dekat muara sungai. Lumpur memiliki substansi yang lebih kompleks daripada pasir dan memiliki bahan organik yang lebih tinggi. Lumpur sendiri terdiri dari pasir, akan tetapi bahan vang lebih penting adalah silt dan clay (Parson dan Takahashi, 1977) sedangkan menurut Nybakken (1992), sedimen lumpur yang baik hanya dapat terbentuk pada dasar yang pergerakan ombaknya rendah atau letaknya lebih dalam sehingga tidak terlalu dipengaruhi ombak.

Kepadatan hewan makrobenthos akan makin menurun dengan makin dalamnya perairan (Hutabarat dan Evans, 1991).

Suhu perairan merupakan salah satu faktor penting dalam metabolisme dan distribusi organisme perairan. Suhu perairan berpengaruh sangat kompleks terhadap hewan benthos, baik secara langsung maupun melalui interaksi dengan faktor kualitas air lainnya (Hawkes, 1978).

Kecerahan merupakan parameter untuk menyatakan sebagian dari cahaya matahari yang menembus ke dalam air. Kecerahan suatu perairan sangat dipengaruhi oleh kekeruhan. Secara langsung, kekeruhan akan mempengaruhi komunitas hewan benthos pada perairan tersebut (Hawkes, 1978).

Secara umum kecepatan arus, langsung maupun tidak langsung mempengaruhi keadaan substrat dasar yang merupakan faktor yang sangat menentukan komposisi hewan benthik, gerakan ombak akan menambah jumlah oksigen dalam air dan mempengaruhi partikel penyusun substrat dasar yang merupakan faktor yang menentukan komunitas benthos (Hawkes, 1978).

Secara umum kecepatan arus, langsung maupun tidak langsung mempengaruhi keadaan substrat dasar yang merupakan faktor yang sangat menentukan komposisi hewan benthik, gerakan ombak akan menambah jumlah oksigen dalam air dan mempengaruhi partikel penyusun substrat dasar yang merupakan faktor yang menentukan komunitas benthos (Hawkes, 1978).

$\mathrm{pH}$ merupakan faktor pembatas bagi kehidupan komunitas benthos. Masing-masing jenis organisme mempunyai toleransi yang berbeda tergantung pada tingkat kejenuhan oksigen terlarut, konsentrasi ion-ion alkalinitas dan jenis serta stadia organisme (Jones, 1964).

Menurut Nybakken (1992), perubahan salinitas pada zona intertidal akan menimbulkan masalah tekanan osmotik bagi organisme intertidal yang kebanyakan menunjukan toleransi yang terbatas terhadap perubahan salinitas. Kisaran yang masih dapat ditolerir oleh hewan makrobenthos adalah $15 \%$ o $-30 \%$ o.

Parson dan Takahashi (1977), mencatat bahwa substrat dasar yang tersusun atas pasir kasar berlumpur umumnya akan dihuni lebih banyak hewan makrobenthos per unit area dibandingkan dengan dasar perairan yang tersusun atas lempung berpasir.

Hakim (1986), menyatakan bahwa bahan organik tanah merupakan hasil perombakan dan penyusunan yang dilakukan jasad renik tanah. Sumber utama bahan organik tanah adalah jaringan tanaman, kotoran maupun hewan yang telah mati yang selanjutnya akan mengalami proses perombakan yang pada akhirnya menjadi bahan organik tanah.

Penelitian menggunakan metode deskriptif yang bersifat studi kasus. Studi kasus adalah metode penelitian dengan menelaah secara mendalam suatu 
masalah pada suatu waktu tertentu dan hasil yang didapat belum tentu sama pada daerah lain meskipun obyek penelitiannya sama. Pengumpulan data dilakukan dengan cara observasi di lapangan yaitu dengan melakukan pengamatan dan pencatatan secara sistematis baik langsung maupun tak langsung mengenai kejadian yang diselidiki dalam suatu penelitian dan hasilnya diharapkan dapat menggambarkan sifat populasi dan obyek penelitian (Sudjana, 1986).

Metode pengambilan sampel yang digunakan adalah sistematik sampling, yaitu anggota sampel diambil dari populasi pada jarak interval waktu, ruang atau urutan yang seragam. Diharapkan dengan menggunakan metode mi akan didapatkan sampel yang mewakili populasi yang diamati (Sudjana, 1986)

Penentuan lokasi sampling penelitian ini adalah daerah perairan terbuka dan perairan tertutup. Tempat pengambilan sampel sebagai Stasiun I adalah daerah perairan tertutup, sedangkan untuk Stasiun II adalah daerah perairan terbuka. Pengambilan sampel hewan makrobenthos dilakukan dengan cara menekan pipa paralon berdiameter $10 \mathrm{~cm}$ ke dalam substrat sedalam $30 \mathrm{~cm}$ pada tiap lokasi penelitian serta mengambil substrat yang tertampung pada alat tersebut. Identifikasi hewan makrobenthos menggunakan buku acuan Day a (1967), Day b (1967), Sars (1890), dan Roberts dkk (1982).

Analisis data agar sesuai dengan permasalahan dan tujuan penelitian maka data yang telah terkumpul selanjutnya diolah dan disajikan secara deskriptif Analisis data dilakukan dengan menghitung keanekaragaman dan keseragaman dangan rumus dari Odum (1971). Untuk mengetahui apakah terdapat pengaruh perairan terbuka-tertutup terhadap (X2) dengan analisis kontingensi (Sudjana, 1986).

\section{Hasil dan Pembahasan}

Penelitian ini dilakukan di Teluk Awur yang termasuk dalam wilayah administratif Kabupaten Jepara yang terletak di sebelah utara Kampus Lima Kelautan Universitas Diponegoro. Perairan ini terletak antara $110^{\circ} 30^{\prime} \mathrm{BT}-110^{\circ} 35^{\prime} \mathrm{BT}$ dan $6^{\circ} 47^{\prime} \mathrm{LS}$ (Dinas Perikanan Kabupaten Jepara,). Pada lokasi penelitian stasiun terbuka, sering terjadi gerakan air seperti gelombang serta arus yang cukup besar sehingga mengganggu ketenangan hewan makrobenthos pada lokasi ini. Sebaliknya pada lokasi penelitian stasiun tertutup, jarang ada arus serta gelombang yang besar sehingga ketenangan hewan makrobenthos yang ada di lokasi penelitian tidak terganggu (Brafield, 1978). Untuk dapat lebih jelas mengetahui populasi dan keanekaragaman hewan makrobenthos yang ditemukan pada perairan tertutup dan terbuka dapat dilihat pada histogram berikut ini.

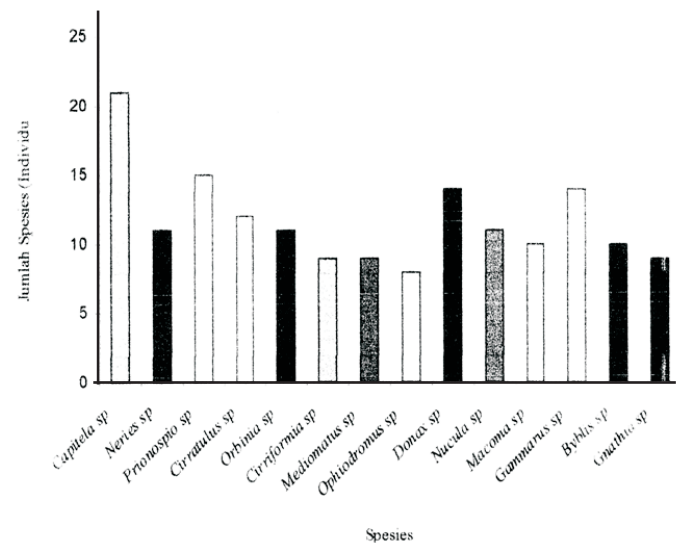

Gambar 1. Histogram hewan Makrobenthos pada perairan tertutup

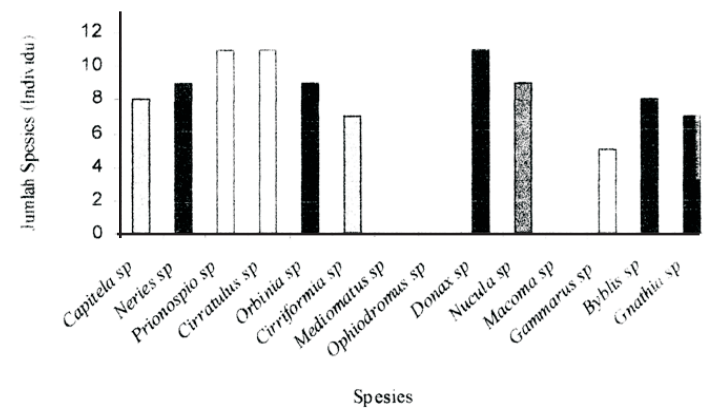

Gambar 2. Histogram hewan Makrobenthos pada perairan terbuka

Populasi hewan makrobenthos lebih besar pada perairan tertutup dibandingkan perairan terbuka. Hal ini berkaitan dengan kondisi lingkungan pada perairan tersebut. Pada perairan terbuka, hewan makrobenthos mengalami gangguan dan terpaan arus dan gelombang yang menyebabkan teraduknya substrat dimana hewan makrobenthos tersebut hidup, sehingga jumlahnya lebih sedikit dibandingkan perairan tertutup yang tidak mengalami gangguan. Pada perairan terbuka jika terjadi pengadukan substrat sampai sedalam $1 \mathrm{~m}$ maka semua hewan benthos secara fisik dapat terambil (Hart et al.,1977), Gerakan ombak merupakan faktor lingkungan yang dominan beraksi di perairan ini, sehingga banyak organisme mengalami kesulitan menyesuaikan (Brafield, 1978). Menurut Wardoyo (1975), pada hakekatnya hewan makrobenthos mempunyai batas toleransi terhadap lingkungan hidupnya. 
Tabel 1. Populasi dan Keanekaragaman Hewan Makrobenthos selama Penelitian (individu/0,057m3)

\begin{tabular}{|c|c|c|c|c|c|c|c|c|c|c|c|c|c|c|c|c|c|c|c|}
\hline \multirow{2}{*}{ No. } & \multirow{2}{*}{ Biota } & \multicolumn{8}{|c|}{ Tertutup } & \multicolumn{10}{|c|}{ Terbuka } \\
\hline & & 1 & 2 & 3 & 4 & 5 & 6 & 7 & 8 & Total & 1 & 2 & 3 & 4 & 5 & 6 & 7 & 8 & Total \\
\hline & Polychaeta & & & & & & & & & & & & & & & & & & \\
\hline 1 & Capitela sp. & 4 & 2 & 0 & 3 & 2 & 3 & 4 & 3 & 21 & 0 & 2 & 1 & 2 & 0 & 2 & 1 & 0 & 8 \\
\hline 2 & Nereis sp. & 0 & 1 & 3 & 0 & 2 & 1 & 2 & 2 & 11 & 2 & 0 & 3 & 0 & 2 & 2 & 0 & 0 & 9 \\
\hline 3 & Prionospio sp. & 3 & 2 & 0 & 3 & 0 & 2 & 3 & 2 & 15 & 2 & 2 & 1 & 2 & 0 & 2 & 0 & 2 & 11 \\
\hline 4 & Cirratulus sp. & 1 & 3 & 3 & 1 & 1 & 2 & 0 & 1 & 12 & 1 & 2 & 0 & 2 & 0 & 3 & 2 & 1 & 11 \\
\hline 5 & Orbinia sp. & 2 & 2 & 1 & 0 & 2 & 1 & 2 & 1 & 11 & 2 & 0 & 3 & 0 & 2 & 0 & 2 & 0 & 9 \\
\hline 6 & Cimformia sp. & 2 & 0 & 2 & 1 & 2 & 0 & 1 & 1 & 9 & 0 & 2 & 0 & 2 & 1 & 0 & 0 & 2 & 7 \\
\hline 7 & Mediomatus sp. & 1 & 3 & 1 & 0 & 1 & 1 & 2 & 0 & 9 & 0 & 0 & 0 & 0 & 0 & 0 & 0 & 0 & 0 \\
\hline 8 & Ophiodromus sp. & 0 & 1 & 2 & 2 & 1 & 0 & 0 & 2 & 8 & 0 & 0 & 0 & 0 & 0 & 0 & 0 & 0 & 0 \\
\hline 9 & Donax sp. & 3 & 2 & 1 & 0 & 4 & 0 & 2 & 2 & 14 & 1 & 3 & 0 & 2 & 2 & 0 & 1 & 2 & 11 \\
\hline 10 & Nucula sp. & 2 & 3 & 2 & 2 & 0 & 1 & 0 & 1 & 11 & 2 & 2 & 2 & 0 & 0 & 2 & 1 & 0 & 9 \\
\hline 11 & Macoma sp. & 2 & 2 & 1 & 0 & 2 & 0 & 2 & 1 & 10 & 0 & 0 & 0 & 0 & 0 & 0 & 0 & 0 & 0 \\
\hline 12 & Gammarus sp. & 2 & 3 & 2 & 0 & 3 & 1 & 1 & 2 & 14 & 0 & 0 & 1 & 0 & 1 & 0 & 0 & 2 & 5 \\
\hline 13 & $\mathrm{Byb} / \mathrm{is} \mathrm{sp.}$ & 0 & 1 & 3 & 3 & 0 & 2 & 0 & 1 & 10 & 0 & 2 & 0 & 2 & 0 & 1 & 1 & 2 & 8 \\
\hline 14 & Gnathia sp. & 2 & 1 & 2 & 1 & 0 & 0 & 1 & 2 & 9 & 1 & 0 & 1 & 0 & 1 & 1 & 1 & 0 & 7 \\
\hline & Junlah & & & & & & & & & 164 & & & & & & & & & 95 \\
\hline
\end{tabular}


Tabel 2. Indeks Keanekaragaman Hewan Makrobenthos selama Penelitian (individu/0,057m3)

\begin{tabular}{|c|c|c|c|c|c|c|c|c|c|}
\hline \multirow{3}{*}{ No. } & \multirow{3}{*}{$\begin{array}{c}\text { Biota } \\
\text { Polychaeta }\end{array}$} & \multicolumn{8}{|c|}{ Stasiun } \\
\hline & & \multicolumn{4}{|c|}{ Tertutup } & \multicolumn{4}{|c|}{ Terbuka } \\
\hline & & ni & $\mathrm{Ni} / \mathrm{N}$ & Ln ni/N & $\mathrm{H}^{\prime}$ & ni & $\mathrm{Ni} / \mathrm{N}$ & Ln ni/N & $\mathrm{H}^{\prime}$ \\
\hline 1 & Capitela sp. & 21 & 0.1280 & -2.0553 & 0.2632 & 8 & 0.0842 & 2.4744 & 02084 \\
\hline 2 & Nereis sp. & 11 & 0.0671 & -2.7020 & 0.1812 & 9 & 0.0947 & 2.3567 & 02233 \\
\hline 3 & Prionospio sp. & 15 & 0.0915 & -2.3918 & 0.2188 & 11 & 0.1158 & 2.1560 & 02496 \\
\hline 4 & Cirratulus sp. & 12 & 0.0732 & -2.6150 & 0.1913 & 11 & 0.1158 & 2.1560 & 0.2496 \\
\hline 5 & Orbinia sp. & 11 & 0.0671 & -2.7020 & 0.1812 & 9 & 0.0947 & 2.3567 & 02233 \\
\hline 6 & Cimformia sp. & 9 & 0.0549 & -2.9026 & 0.1593 & - & 0.0737 & 2.6080 & 01922 \\
\hline 7 & Mediomatus sp. & 9 & 0.0549 & -2.9026 & 0.1593 & 0 & 0.0000 & 0.0000 & 0.0000 \\
\hline 8 & Ophiodromus sp. & 8 & 0.0488 & -3.0204 & 0.1473 & 0 & 0.0000 & 0.0000 & 0.0000 \\
\hline 9 & Donax sp. & 14 & 0.0854 & -2.4608 & 0.2101 & 11 & 0.1158 & 2.1560 & 02496 \\
\hline 10 & Nucula sp. & 11 & 0.0671 & -2.7020 & 0.1812 & 9 & 00947 & 2.3567 & 0.2233 \\
\hline 11 & Macoma sp. & 10 & 0.0610 & -2.7973 & 0.1706 & 0 & 0.0000 & 0.0000 & 0.0000 \\
\hline 12 & Gammarus sp. & 14 & 0.0854 & -2.4608 & 0.2101 & 5 & 00526 & 2.9444 & 01550 \\
\hline 13 & Byb/is sp. & 10 & 0.0610 & -2.7973 & 0.1706 & 8 & 0.0842 & 2.4744 & 0.2084 \\
\hline \multirow[t]{2}{*}{14} & Gnathia sp. & 9 & 0.0549 & -2.9026 & 0.1593 & 7 & 0.0737 & 2.6080 & 0.1922 \\
\hline & Jumlah & 164 & & & 2.6035 & 95 & & & 2.3748 \\
\hline
\end{tabular}

Tabel 3. Indeks keseragaman hewan Makrobenthos selama penelitian

\begin{tabular}{|c|c|c|c|c|c|}
\hline No. & Stasiun & $\mathrm{T}$ & $\mathrm{H}$, & $\begin{array}{c}\text { H maks } \\
\text { (Ln S) }\end{array}$ & $\mathrm{e}$ \\
\hline 1 & Tertutup & 14 & 2.603 & 2.639 & 0.9865 \\
2 & Terbuka & 11 & 2.375 & 2.398 & 0.9303 \\
\hline
\end{tabular}


Untuk dapat lebih mengetahui indeks keanekaragaman dan keseragaman hewan makrobenthos pada stasiun tertutup dan terbuka dapat dilihat pada histogram berikut.

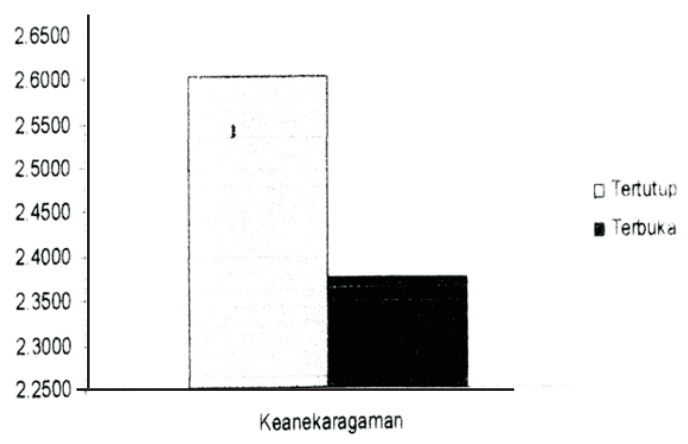

Gambar 3. Histogram indeks keanekaragaman hewan Makrobenthos pada perairan tertutup dan terbuka

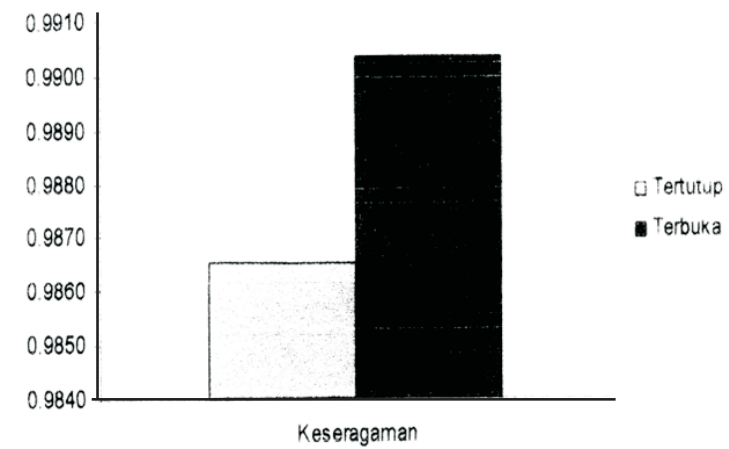

Gambar 4. Histogram indeks keseragaman hewan Makrobenthos pada perairan tertutup dan terbuka

Tabel 4. Analisis substrat dasar perairan pada lokasi penelitian

\begin{tabular}{|c|c|c|c|c|c|c|c|c|}
\hline \multirow{2}{*}{ No. } & \multirow{2}{*}{ Stasiun } & \multicolumn{5}{|c|}{ Pasir } & & Lumpur \\
\cline { 3 - 8 } & & $\begin{array}{c}\text { Kasar } \\
(\%)\end{array}$ & $\begin{array}{c}\text { Sedang } \\
(\%)\end{array}$ & $\begin{array}{c}\text { Halus } \\
(\%)\end{array}$ & $\begin{array}{c}\text { Sangat } \\
\text { halus (\%) }\end{array}$ & Total (\%) & $\begin{array}{c}\text { Lempug } \\
(\%)\end{array}$ \\
\hline 1 & Tertutup & 44.08 & 11.40 & 37.44 & 7.08 & 100 & 0 & 0 \\
2 & Terbuka & 64.72 & 28.16 & 6.60 & 0.02 & 100 & 0 & 0 \\
\hline
\end{tabular}

Tabel 5. Parameter kualitas perairan pada lokasi penelitian

\begin{tabular}{|c|c|c|c|}
\hline \multirow{2}{*}{ Parameter } & \multicolumn{2}{|c|}{ Stasiun } & \multirow{2}{*}{ Pustaka } \\
\hline & Tertutup & Terbuka & \\
\hline Suhu $\left({ }^{\circ} \mathrm{C}\right)$ & 29.5 & 29.2 & 25-30 (Kozloff, 1990) \\
\hline Kecepatan Arus (cm/dt) & 7 & 15 & 12-20 (McLusky, 1971) \\
\hline pH Air & 8.4 & 8.2 & 6.6-8.5 (Nybakken, 1992) \\
\hline Salinitas (ppt) & 36 & 35 & 27-42 (Kozloff, 1990) \\
\hline Kedalaman $(\mathrm{cm})$ & 13 & 16 & 100-125 (Nybakken, 1992) \\
\hline Kecerahan $(\mathrm{cm})$ & 13 & 16 & 15-150 (Nybakken, 1992) \\
\hline Bahan Organik & 4.03 & 4.32 & $<3.5-35$ (Fort, 1979) \\
\hline
\end{tabular}


Kelas Polychaeta mendominasi populasi hewan makrobenthos sebesar 58\% pada perairan tertutup dan $57 \%$ pada perairan terbuka, Bivalve $21 \%$ perairan tertutup dan terbuka, Crustacea $20 \%$ pada perairan tertutup dan pada perairan terbuka. Hal ini sesuai dengan pendapat Thorson (1966) yang menyatakan bahwa kelompok Polychaeta ditemukan paling banyak dengan komposisi 40 - 80\%, sedangkan Crustacea 3 - 50\%, Mollusca 5 - 10\% serta Echinodermata 1-2\%.

Bivalve dan Crustacea, selain disebabkan karena komposisinya di alam yang berbeda juga erat kaitannya dengan kemampuan membenamkan diri ke dalam substrat untuk menghindari hempasan arus terutama pada perairan terbuka yang berarus besar. Barnes (1980) menyatakan bahwa jenis Bivalve mampu membenamkan diri pada kedalaman 12 - 25 $\mathrm{cm}$, sedangkan jenis Crustacea mampu membenamkan diri sampai kedalaman $14 \mathrm{~cm}$. Bivalve yang paling banyak ditemukan adalah jenis Donax sp.. Hal ini disebabkan karena Donax sp. dapat bergerak ke atas dan ke bawah serta membenamkan dirinya di pantai dengan sangat cepat (dalam waktu detik) dan siap untuk mencari makanan pada saat ombak kembali ke laut setelah pecah dan pantai (Brafield, 1978). Jumlah Donax sp. pada perairan terbuka dan tertutup tidak terlalu besar perbedaannya yaitu pada perairan terbuka jumlahnya 14 spesies sedangkan pada perairan tertutup jumlahnya 11 spesies, hal ini disebabkan karena Donax sp. cenderung hidup di pasir. Menurut Jerome (1981) dan Walter (1978) kehidupan Donax sp. adalah perairan yang berombak keras dan berhabitat pasir. Crustacea mempunyai populasi yang lebih sedikit dibandingkan dengan Polychaeta. Hal ini disebabkan karena Crustacea merupakan hewan makrobenthos yang menghuni permukaan substrat (Nybakken, 1992). Sehingga kehidupannya akan lebih terganggu arus dan gelombang terutama pada perairan terbuka.

Populasi hewan makrobenthos di alam dapat kembali normal dengan berpindahnya hewan makrobenthos tersebut ke daerah yang tidak terpengaruh oleh pengerukan substrat. Hal ini sesuai dengan Hart, et al. (1977) bahwa populasi hewan makrobenthos dapat kembali pada kondisi sebelum terjadi pengerukan substrat dalam waktu 12 hari pada daerah yang terjadi pengerukan dan 10 hari pada daerah yang dekat dengan gangguan pengerukan.

Pada Tabel 5, indeks keanekaragaman untuk perairan tertutup adalah 2,6035 dan untuk perairan terbuka adalah 2,3748. Sedangkan pada Tabel 6, indeks keseragaman pada perairan tertutup adalah 0,9865 sedangkan untuk perairan terbuka adalah 0,9903 .
Kisaran ini menurut Wilhm dan Doris (1968) masih layak untuk kehidupan hewan makrobenthos. Indeks keseragaman akan mencapai nilai maksimum jika kelimpahan individu per jenis menyebar secara merata Nilai indeks keseragaman berkisar antara 0-1, semakin besar nilamya maka jumlah individu yang didapatkan semakin seragam. Masih menurut Wilhm dan Doris (1968), semakin kecil suatu nilai indeks keseragaman semakin kecil pula keseragaman spesies atau genera dalam komunitas, artinya apabila penyebaran jumlah individu setiap spesies atau genera tidak sama maka ada kecenderungan suatu komunitas menunjukan keseragaman spesies atau genera sama atau tidak jauh berbeda dan dominasi spesies atau genera tertentu kecil sekali atau tidak terdapat dominasi. Kemudian menurut Brower et al. (1990), nilai indeks keseragaman lebih dari 0,6 termasuk dalam kategori keseragaman populasi tinggi. Kategori tersebut secara umum menunjukkan bahwa komposisi hewan makrobenthos pada perairan tertutup dan terbuka tidak memperlihatkan adanya dominasi spesies. Terlihat bahwa indeks keanekaragaman yang besar belum tentu diikuti nilai keseragaman yang besar pula. Kenyataan ini dikarenakan indeks keanekaragaman dipengaruhi oleh jumlah jenis dan jumlah individu setiap jenis hewan makrobenthos. Untuk indeks keseragaman selain ditentukan oleh jenis dan kelimpahan individu juga ditentukan oleh tingkat pemerataan individu yang ada (Krebs, 1978).

Perbedaan populasi dan keanekaragaman hewan makrobenthos pada perairan terbuka dan tertutup. Dengan menggunakan uji Chi-Kuadrat untukmengetahui perbedaan populasi dan keanekaragaman hewan makrobenthos pada perairan tertutup dan terbuka didapatkan hasil sebagai berikut:

$\mathrm{X} 2$ hitung $=22.658>\mathrm{X} 2$ tabel $0,95(13)=22,4$

Sesuai dengan kaidah maka diputuskan untuk menolak Ho dan terima H1. Hal ini berarti perairan tertutup dan perairan terbuka memberikan pengaruh terhadap perbedaan populasi dan keanekaragaman hewan makrobenthos.

Perairan Teluk Awur mempunyai kondisi perairan yang berbeda, yaitu perairan tertutup dan terbuka. Perbedaan kondisi perairan tersebut menyebabkan perbedaan faktor fisika dan kimia. Akan tetapi faktor yang lebih menonjol pada perairan ini adalah arus dan gelombang. Akibat dari arus dan gelombang tersebut menimbulkan perairan terbuka memiliki turbulensi dan terjadi pengadukan substrat dasar pada perairan tersebut yang akan mempengaruhi terhadap hewan makrobenthos di dalamnya Sebagaimana diungkapkan Brafield (1978), gerakan 
ombak merupakan faktor lingkungan yang dominan beraksi di perairan ini, sehingga banyak organisme mengalami kesulitan menyesuaikan diri. Selain arus, faktor fisika lain yang berpengaruh terhadap perbedaan populasi dan keanekaragaman hewan makrobenthos pada perairan tertutup dan terbuka adalah suhu, kedalaman dan kecerahan. Akan tetapi faktor-faktor tersebut menunjukan nilai yang tidak terlalu besar antara perairan tertutup dan terbuka sehingga perbedaan faktor-faktor tersebut bukan merupakan penyebab utama dalam menentukan perbedaan populasi dan keanekaragaman hewan makrobenthos pada lokasi penelitian. Pada Tabel 8 menunjukkan kecepatan arus pada lokasi perairan terbuka sebesar $15 \mathrm{~cm} / \mathrm{dt}$ sedangkan pada perairan tertutup hanya sebesar $7 \mathrm{~cm} / \mathrm{dt}$. Akibat arus tersebut, perairan terbuka lebih dipengaruhi ombak dibandingkan pada perairan tertutup. Menurut Mann (1982), perairan terbuka adalah perairan yang tidak terlindung serta dipengaruhi oleh ombak dan gelombang. Menurut McNoughton dan Wolf (1990), semakin tinggi kecepatan arus maka akan mengganggu kestabilan substrat dasar sehingga akan mengganggu kestabilan hewan makrobenthos yang ada di dalamnya. Akibatnya populasi dan keanekaragaman hewan makrobentos lebih besar pada perairan tertutup dibandingkan pada perairan terbuka.

Pada Tabel 4 dapat dilihat populasi dan keanekaragaman hewan makrobenthos pada perairan tertutup sebanyak 164 individu yang terdin dari 14 spesies. Sedangkan pada perairan terbuka terdapat 95 individu yang terdiri dari 11 spesies Dari jumlah ersebut terbagi atas Polychaeta sebesar 58\% pada perairan tertutup dan $57 \%$ pada perairan terbuka, Bivalve $21 \%$ pada perairan tertutup dan terbuka, Crustacea $20 \%$ pada perairan tertutup dan $21 \%$ pada perairan terbuka. Pada Tabel 5, indeks keanekaragaman hewan makrobenthos selama penelitian adalah 2,6035 pada stasiun tertutup, sedangkan pada stasiun terbuka adalah 2,3748. Pada Tabel 6, indeks keseragaman hewan makrobenthos menunjukkan bahwa keseragaman pada perairan tertutup sebesar 0,987 sedangkan pada perairan terbuka sebesar 0,990 dari tabel tersebut dapat diketahui bahwa indeks keseragaman pada stasiun tertutup lebih besar jika dibandingkan dengan stasiun terbuka. Hal ini menunjukkan bahwa perairan tertutup mempunyai pengaruh yang besar terhadap keanekaragaman dan keseragaman hewan makrobenthos, karena perairan tertutup mempunyai kondisi yang tenang sehingga kehidupan hewan makrobenthos relatif tidak terganggu. Kesulitan untuk beradaptasi dengan kondisi dan faktor-faktor tersebut akan mempengaruhi populasinya. Hal ini dapat dimengerti karena pada hakekatnya hewan-hewan tersebut mempunyai batas toleransi yang berbeda terhadap lingkungan hidupnya (Wardoyo, 1975).

Pada Tabel 5 dan 6 dapat dilihat bahwa kelas Polychaeta ditemukan dalam jumlah yang lebih besar dibandingkan kelas lainnya baik pada perairan tertutup maupun perairan terbuka. Akan tetapi indeks keanekaragaman dan keseragamannya menunjukkan nilai yang tidak terlalu besar. Perbedaan indeks keanekaragaman dan keseragaman hewan makrobenthos hanya terletak pada jumlah individu yang ditemukan. Hal ini sesuai dengan pendapat Nybakken (1992), perbedaan indeks keanekaragaman dan indeks keseragaman hanya terletak pada komposisi atau kepadatan nisbi dari kelompok organisme penyusunnya.

Hasil pengukuran kedalaman pada perairan tertutup berkisar antara $13 \mathrm{~cm}$, sedangkan pada perairan terbuka berkisar antara $16 \mathrm{~cm}$. Perbedaan kedalaman tersebut tidak terlalu mencolok antara perairan terbuka dan perairan tertutup karena pengukuran dilakukan pada saat pasang tertinggi pada daerah yang masih ombak. Kedalaman berpengaruh terhadap intensitas cahaya matahari ke dalam perairan. Cahaya matahari tersebut akan mempengaruhi suhu yang juga akan mempengaruhi kandungan bahan organik, selain hal tersebut cahaya matahari juga akan mempengaruhi hewan makrobenthos yang berada pada dasar perairan (Nybakken, 1992).

Hasil pengukuran menunjukkan bahwa suhu perairan Teluk Awur berkisar antara $29^{\circ} \mathrm{C}$ untuk perairan terbuka dan $28^{\circ} \mathrm{C}$ untuk perairan tertutup, perbedaan ini disebabkan karena waktu pengukuran di kedua lokasi tidak persis sama. Akan tetapi kisaran suhu ini masih dalam batas yang layak untuk kehidupan hewan makrobenthos. Adapun suhu yang baik untuk organisme perairan adalah berkisar antara 25 - $30{ }^{\circ} \mathrm{C}$ (Wardoyo, 1975). Jika suhu tersebut terlampaui maka organisme akan menjadi semakin lemah karena suhu ekstrim sehingga tidak dapat menjalankan kegiatan seperti biasa.

Hasil pengukuran kecerahan pada kedua stasiun sampling menunjukkan nilai yang sama dengan nilai kedalamannya. Hal ini disebabkan selain karena kondisi kedalaman pada lokasi penelitian cukup rendah juga menunjukkan kondisi perairan jernih. Kondisi kecerahan akan mempengaruhi kehidupan hewan makrobenthos. Sebagaimana diungkapkan Hawkes (1978), secara tidak langsung jumlah cahaya yang mampu masuk ke dalam air (yang selanjutnya 
disebut parameter kecerahan air) akan mempengaruhi hewan makrobenthos di dasar perairan. Kedalaman dan kecerahan merupakan dua hal yang tidak dapat dipisahkan, karena kecerahan juga dipengaruhi kedalaman. Perkins (1974) menyatakan bahwa kedalaman perairan berpengaruh terhadap jumlah cahaya matahari yang masuk dan mencapai dasar perairan.

Hasil pengukuran kecepatan arus pada lokasi penelitian rata-rata sebesar $7 \mathrm{~cm} / \mathrm{dt}$ untuk perairan tetutup, sedangkan untuk perairan terbuka rata-rata sebesar $15 \mathrm{~cm} / \mathrm{dt}$. Kecepatan arus tersebut masih di bawah kecepatan kritis air yaitu $20 \mathrm{~cm} / \mathrm{dt}$ (McNougthon dan Wolf, 1990). Kecepatan arus yang tinggi akan mengganggu kestabilan substrat dasar sehingga akan mengganggu kestabilan hewan makrobenthos yang ada di dalamnya. Kecepatan arus selain membantu ketersediaan bahan makanan dan penyebaran larva hewan makrobenthos juga mempengaruhi susunan partikel penyusun substrat dasar yang merupakan faktor penentu distribusi hewan makrobenthos.

Hasil pengukuran derajat keasaman pada kedua lokasi menunjukkan nilai rata-rata 7. Kisaran $\mathrm{pH}$ tersebut berada dalam batas yang layak bagi kehidupan organisme perairan yaitu 6,6, - 8,5 (Mann, 1982). Lebih lanjut oleh Mann( 1955) dalam Hawkes (1978), sebagian gastropoda hidup pada kisaran $\mathrm{pH}$ lebih besar dari 7 sedangkan Bivalve hidup dengan kisaran pH 5,6 $-8,3$.

Berdasarkan pengamatan yang telah dilakukan selama penelitian di kedua lokasi didapatkan nilai salinitas 33 - 34\%o. Kisaran tersebut masih sesuai untuk kehidupan hewan makrobenthos karena kisaran yang masih bisa diloleransi oleh hewan makrobenthos adalah 15 - 30\%o (Hutabarat dan Evans, 1991).

Hasil pengukuran substrat pada perairan tertutup dan terbuka seluruhnya berupa pasir. Pada kondisi substrat dasar pasir, kehidupan hewan makrobenthos sangat terganggu, karena lebih terpengaruh arus dan gelombang yang mengenainya. Parson dan Takahashi (1977), jika ada ombak atau arus yang datang maka substrat dasar akan memberai sehingga hal tersebut akan mengganggu kelangsungan hidup hewan makrobenthos yang ada pada perairan terbuka. Sedangkan pada lokasi stasiun tertutup akan terpengaruh juga karena pada stasiun ini substrat dasarnyapun berupa pasir tetapi pengaruhnya akan lebih besar pada stasiun terbuka karena pada stasiun terbuka kekuatan arus dan gelombangnya lebih besar dibandingkan stasiun tertutup.
Hasil pengukuran bahan organik pada perairan tertutup 4,03 dan perairan terbuka adalah 4,32. Kisaran tersebut berada dalam kriteria bahan organik rendah (Forth, 1979).

\section{Daftar Pustaka}

Barnes, D.R. 1980. Invertebrate Zoology. Fourth Edition. W. B Saunders College, West Washington Square: Philadelphia

Brafield, A.E. 1978. Life in Sandy Shores. First Edition. Edward Arnold Publishers : London

Brower JE, JH Zar, CN Ende von. 1990. Field and Laboratory Methods foi General Ecology Dubuque. WCB Publishers.

C.W. Hart, Jr., and Samuel L. H. Fuller (eds). 1979. Pollution Ecology oi Estuarine Invertebrates. Academic Press. New York

Daya5 J H. 1967. A Monograph On The Polychaeta Of Southern Africa Pt.I.Errrantia. British Museum (Natural Museum), London,

Dayb, J H. 1967. A Monograph On The Polychaeta Of Southern Africa Pt.ILSedentaria. British Museum (Natural Museum), London

Fort, H D. 1979. Dasar-dasar Ilmu Tanah. (Penerjemah Soenarto Adi Sumarto). Erlangga, Jakarta.

Godman, A. 1989. Kamus Sains Bergambar. Gramedia. Jakarta

Hakim, N. 1986. Dasar-dasar Ilmu Tanah. Universitas Lampung

Hawkes, H.A. 1978. Invertebrate as Indicator of River Water Quality. In A. James and L. Evinson.(Eds). Biological Indicators of Water Quality John Wiley anc sons : Toronto

Hutabarat, S dan S.M. Evans. 1991. Pengantar Oseanografi. Universitas Indonesia : Jakarta

Jerome, M.E. 1981. A Collectors's guide to sea shells of the world. Mc Graw-Hill Book Company. New York

Jones, J.R.E. 1964. Fish and Marine Pollution. Butterworth and Co, Ltd London

Kozlof, E.N. 1990. Inverebrates. Sounders College Publishing: Philadelphia

Krebs, C.J. 1978. Ecology, The Experimental Analysis of Distribution anc Abundance. Harper and row (Publisher). Harper International Edition: New York

Mann, K.H. 1982. Ecology of Coastal Waters : A System Approach. Blackwei: Scientific Publications : London

McLusky, D.S. 1971. Ecology of Estuaries. The Scholarship, Hememann Education Books Ltd: London. 
McNoughton, S.J dan Wolf Larry L. 1990. Ekologi Umum. Gadjah Mada University Press : Yogyakarta

Nybakken, J.W. 1992. Biologi Laut : Suatu Pendekatan Ekologis. Gramedia : Jakarta

Odum, P.E. 1971. Fundamental of Ecology. 3rd Ed WB. Saunders Company: Philadelphia

Parson, T.R. and M. Takahashi. 1977. Biologycal Oceanographic Processes Pergamon Press : London

Perkins, J. 1974. The Biology of Estuarine and Coastal Water, Academic Press : London

Roberts, D. Soemodihardjo S. and W. Kastoro. 1982. Shallow Water Marine Molluscs of NorthWest Java. Lembaga Oseanologi Nasional LIPI, Jakarta

Sars, GO. 1890. An Account of The Crustacea of Norway Amphipoda Vol 1 Chnstiani and Copenhagen
Setiadi, Dede dan Puspa Dewi Tjondronegoro. 1989. Dasar-dasar Ekologi. Departemen Pendidikan dan Kebudayaan Direktorat Jenderal Pendidikan Tinggi Pusat Antar Universitas Ilmu Hayat. IPB, Bogor

Sudjana. 1986. Metode Statistika. Edisi Keenam. Tarsito: Bandung

Walter, O.C. 1978. Tropical Pacific Marine Shells. Pacific Population: Sidnev

Wardoyo, S.T.H. 1975. Pengelolan Kualitas Air. Proyek Penmgkatan Mutu Perguruan Tinggi. IPB : Bogor

Wilhm, J.L dan Doris. 1968. Biological Parameter for Water Quality Criteria Bio Science: London 